\title{
Financing Solar PV at Government Sites with PPAs and Public Debt
}

Historically, state and local governmental agencies have employed one of two models to deploy solar photovoltaic (PV) projects: (1) self-ownership (financed through a variety of means) or (2) third-party ownership through a power purchase agreement (PPA). Morris County, New Jersey, administrators recently pioneered a way to combine many of the benefits of self-ownership and third-party PPAs through a bond-PPA hybrid, frequently referred to as the Morris Model.

At the request of the Department of Energy's Solar Market Transformation group, NREL examined the hybrid model. This fact sheet:

- Describes how the hybrid model works

- Assesses the model's relative advantages and challenges as compared to self-ownership and the third-party PPA model

- Provides a quick guide to project implementation

- Assesses the replicability of the model in other jurisdictions across the United States.

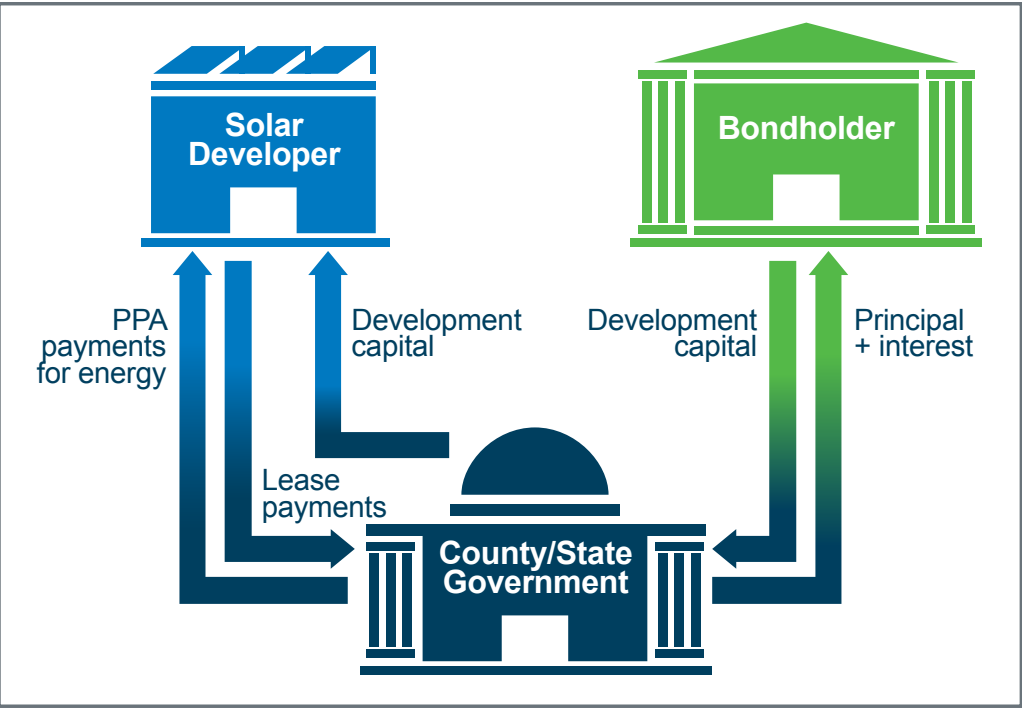

Figure 1. Money transfers in the hybrid model

\section{The Bond-PPA Hybrid}

The hybrid model is a financing option by which a public entity issues a government bond at a low interest rate and transfers that low-cost capital to a developer in exchange for a lower PPA price. ${ }^{1}$ To date, the model has been used to finance solar PV projects on schools, colleges, county administrative buildings, and other public buildings in several jurisdictions in New Jersey. Implementers have achieved notable energy cost savings as compared to projections of their local electricity rate; the four portfolios that have been finalized to date have saved between $\$ 3$ million and $\$ 14.6$ million on a net present value (NPV) basis. The model has potential to be transferred to other states, but it is unknown at this point if governments in other states are planning to implement the model.

Under the model, a public entity (the administrator) issues a request for proposals (RFP) seeking a solar developer to build, operate, and own a solar project or portfolio of projects on public buildings (local hosts). The administrator sells bonds to finance the development costs of the PV installation. The administrator then enters into both a lease-purchase agreement with the winning bidder ${ }^{2}$ and a PPA (on behalf of the local hosts) to buy the electricity from the PV system. Figure 1 shows the relationship and money flows between the bondholder, administrator, and solar developer.

\footnotetext{
${ }^{1}$ These types of arrangements are not unique to New Jersey. For example, the City of Denver provided low-interest capital (raised through appropriations) to a developer to build two Denver International Airport solar projects in 2009 (Morrissey 2011). The city did not provide a construction loan; instead, capital was provided after plant commissioning.

${ }^{2}$ The lease-purchase agreement transfers ownership of the project to the solar developer for federal tax purposes.
} 
Though most governmental bonds in the United States are sold to investors as tax-exempt investments, federal regulations require that bonds issued for private use must be taxable. Bonds issued for the purpose of the hybrid model are considered private use because the proceeds are used to fund a project owned by a private entity. Although the bonds must be issued as taxable investments, the good credit rating of the administrator will often make its borrowing rate less than that of the solar developer. In this model, the solar developer makes lease payments that fully cover the bond payments. These lease payments are lower than the loan payments on funds that the solar developer would otherwise have borrowed. The cost savings mean that the solar developer can offer the administrator an attractive PPA price while still making a strong financial return.

\section{Comparison of Self-Ownership, Hybrid, and Conventional PPA Models}

Previous analyses have shown the relative advantages and challenges of self-ownership and third-party ownership for public entities. Table 1 summarizes the primary conclusions of these analyses.

Table 1. Advantages and Challenges of Third-Party PPAs and Self-Ownership for a Public Entity

\begin{tabular}{|c|c|c|}
\hline & Third-Party PPA & Self-Ownership \\
\hline Advantages & $\begin{array}{l}\text { - No/low upfront outlay of capital } \\
\text { - Ability for tax-exempt entity to benefit } \\
\text { from savings passed on from federal tax } \\
\text { incentives } \\
\text { - Predetermined electricity price for } 15-25 \\
\text { years } \\
\text { - No operating and maintenance } \\
\text { responsibilities } \\
\text { - Path to ownership (if included as an } \\
\text { option in PPA) }\end{array}$ & $\begin{array}{l}\text { Ability to use cheap public debt (through } \\
\text { a tax-exempt debt issuance) } \\
\text { - Full control over a project: design, } \\
\text { operations, and risks } \\
\text { - Ability to choose what to } \\
\text { do with renewable energy } \\
\text { attributes generated by the project (retain } \\
\text { or monetize) }\end{array}$ \\
\hline Challenges & $\begin{array}{l}\text { - The process of negotiating a PPA can be } \\
\text { lengthy and costly } \\
\text { - Public entity has limited control over } \\
\text { project design, operations, and risks } \\
\text { - PPA pricing may be sub-optimal } \\
\text { (developer could receive most of the } \\
\text { financial benefits) } \\
\text { - If PPA term is less than the system useful } \\
\text { life, the host must purchase the system at } \\
\text { fair market value at the end of } \\
\text { the term }\end{array}$ & $\begin{array}{l}\text { The public entity cannot monetize the } \\
\text { value provided by federal renewable } \\
\text { energy tax incentives } \\
\text { - Need expertise to navigate potential } \\
\text { revenues from renewable-portfolio- } \\
\text { standard-driven subsidies } \\
\text { - Debt issues and limitations could prohibit } \\
\text { the model } \\
\text { - Project management requirements }\end{array}$ \\
\hline
\end{tabular}

Source: Cory et al. 2008, Pearlman 2011a.

The hybrid model can provide additional benefits compared to both the self-ownership and third-party PPA models. Like self-ownership, the hybrid model allows the administrator to take advantage of low-cost public debt. Like a third-party PPA, the hybrid model enables the tax-exempt administrator to benefit through savings passed on from federal tax incentives. In addition, the administrator receives fixed electricity costs for a long-term contract and has no operating and maintenance responsibilities for the solar PV equipment.

The hybrid model enhances the third-party PPA model because the public entity is able to provide low-cost capital to the project. By providing capital and assuming financial risk, the public entity has leverage to bargain for a better PPA price. While the public entity may not have full control over project details as in the self-ownership model, the hybrid model allows public entities to negotiate project specifics and contract terms. 
One potential downside of the hybrid model is that transaction costs could be higher than under either the self-ownership or third-party PPA models. Consider that the model requires the state or local government both to issue a bond and to negotiate a PPA. Additionally, the program may have more development costs due to the novelty of the approach. That being said, an administrator can include all of the professional costs incurred (e.g., legal fees and bond issuance costs) in the development costs listed in the RFP. Despite transaction costs, winning PPA bids have still been attractive, ranging from $\$ 0.03 / \mathrm{kWh}$ (for a recent $10 \mathrm{MW}$ project) to $\$ 0.106 / \mathrm{kWh}$ in the first deal, where as might be expected, transaction costs were higher due to the learning process.

Program development time may also be lengthy. The first transaction in Morris County, New Jersey, took around 18 months to finalize (Pearlman 2011b), but subsequent projects have been quicker. One estimate is that it may take eight months to a year from the time the project is announced to when the bond is issued, with an additional year to build the project (Scerbo 2011). It may be possible to compress the model into a 4-5 month schedule, as Salem County, New Jersey, is doing (Scerbo 2011).

Another possible barrier is the credit rating required for the model. Potential administrators will need a strong credit rating (A-AAA) to make the model work. Finally, the deal structure adds an extra layer of liability for the administrator - it is liable to bond holders for bond repayment as well as the third-party developer for PPA payments. The developer assumes some of the project risk, but ultimately the administrator is responsible for bond repayment. Specific terms are usually negotiated in the contract between the developer and the administrator to mitigate this additional risk.

\section{Details of the Agreements of the Hybrid Model}

At the core, the unique arrangement between the administrator and solar developer enables the model. There are three important agreements between the administrator and developer: a lease-purchase agreement, a PPA, and a security agreement. These agreements are summarized in Figure 2.

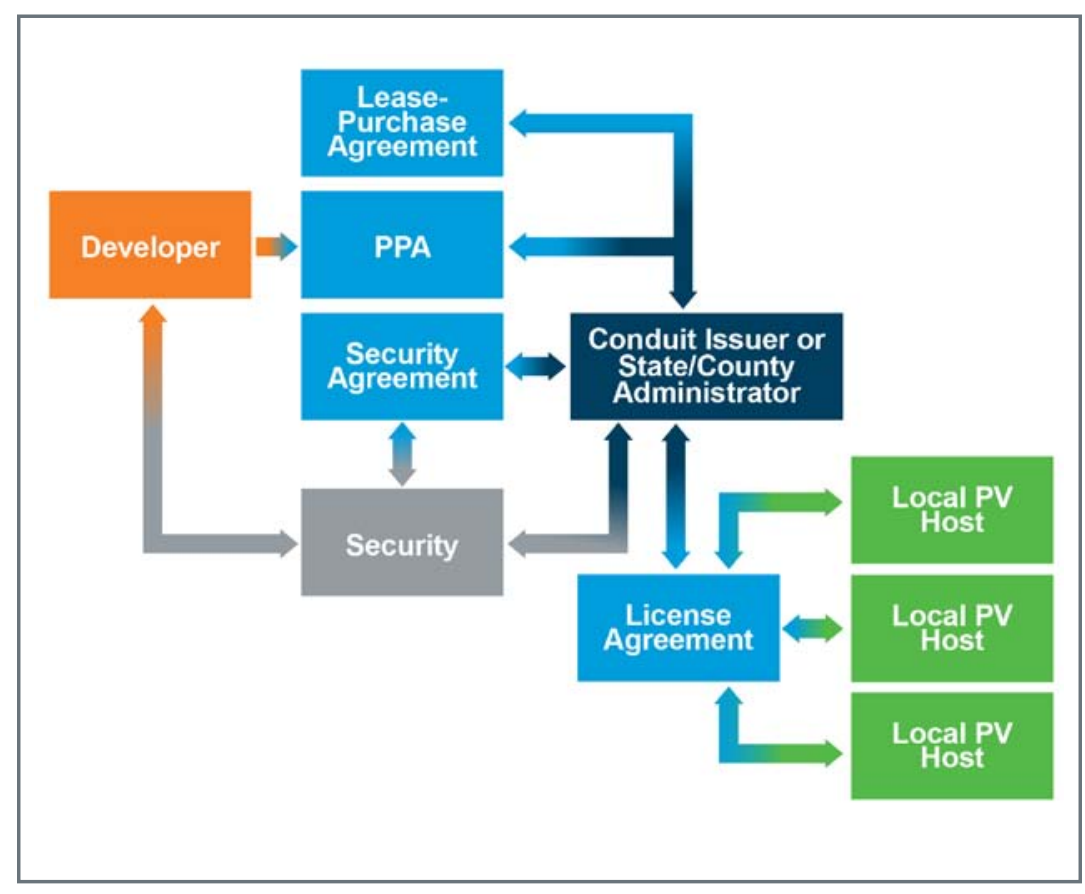

Figure 2. Contract arrangements that comprise the hybrid model

\section{Lease-Purchase Agreement}

The hybrid model requires the arrangement between the administrator and developer to be structured as a capital lease, not a loan. For the purposes of state law, the administrator is considered the project owner/lessor, and the developer is the lessee. However, the terms of the lease-purchase agreement are such that all of the benefits and burdens of ownership are transferred to the developer. This means that for federal tax purposes, the developer owns the project and can take advantage of the investment tax credit or U.S. Treasury cash grant while available. Before the first deal was finalized, the National Tax Council issued an opinion for the developer stating that although the structure is a lease, tax ownership transfers to the developer. The administrator may structure lease repayment as annual amortized payments. The lease-purchase agreement includes annual fees to be paid to the government issuer for administration. 


\section{Power Purchase Agreement}

The developer and the administrator sign a PPA on behalf of the local hosts. One benefit of the hybrid model is that the public entity can negotiate its own terms and conditions. The RFPs issued to date hold the proposing developers harmless against interest rate changes by requiring a PPA price adjustment factor if rates move from proposed submission to bond closing. This reduces the possibility that solar developers will include a market risk premium (Pearlman 2011b). At the expiration of these agreements, the developer owns the PV system. Thus at the end of the term, the PPA counterparties could renew the PPA, the developer could remove the system, or the administrator could purchase the system for its residual value.

\section{Security Agreement}

The security agreement protects the administrator in the event of developer default. The security is provided in two forms: a performance and payment bond and a posted security:

- Performance and payment bond: The developer (or its contractor) must obtain a performance and payment bond for the project, which protects the administrator in the case of construction contract non-performance. The administrator is guaranteed compensation for monetary loss up to the amount of the performance and payment bond.

- Posted security: The developer must also post a form of security that ensures that the administrator can pay its bondholders. Model implementers have developed a formula to establish an appropriate level for this security. It is sized according to what the administrator needs to protect them in the event that the developer walks away. This security protects the administrator up to the "deficiency amount." The deficiency amount is the sum that the administrator owes to the bondholders minus the sum owed to the developer in PPA payments for electricity already delivered and the sum of any revenues generated by the project:

$$
\text { Deficiency amount }=\sum \text { bond principal }+ \text { interest }-\sum P P A \text { payments }-\sum \text { additional revenues (e.g.,SRECs) }
$$

The security requirement can be satisfied in a number of ways, including a parent or affiliate guarantee, a stand-by letter of credit, a direct equity contribution, ${ }^{3}$ or by escrowing the 1603 Treasury cash grant (Somerset County 2011a). If a default on lease payments occurs after the project is built, the developer releases this security and forfeits all rights to the project. The administrator then becomes the project owner, with access to the power and any revenues generated by the project.

\section{Conditions Enabling the Hybrid Model}

Given a basic understanding of the model, it is important for potential implementers to understand what conditions must exist for the model to work. ${ }^{4}$ First, the administrator must have "deep pockets," meaning that its credit rating is strong and that it can assume additional debt. At the county level, it has been estimated that counties rated A-AAA might be able to attract bond investors at a return that would enable the model (Pearlman 2011b).

Additionally, the administrator must be willing to back the bond debt through a full-faith guaranty. Financial officers will want to understand all the risks and benefits of the model before agreeing to a full-faith guaranty. Several factors can increase a public entity's comfort with backing the debt, including:

- Evidence that the transaction will reduce the administrator's operating costs (electricity bills) (note that actual PPA price will not be available at this stage, but some preliminary estimates can be made)

\footnotetext{
${ }^{3}$ Somerset II satisfied the deficiency by eliminating it through a $\$ 12.4$ million equity contribution. After debt was bought down, PPA payments and the assumed solar renewable energy certificate revenues were greater than the debt service obligations (Pearlman 2011b).

${ }^{4}$ Much of this information comes from an interview with Steve Pearlman, one of the attorneys who helped develop the hybrid model.
} 
- Evidence that credit rating agencies are comfortable with the model and will not downgrade the administrator's credit rating

- An open bidding process for selecting the developer

- Assurance that the solar developer is responsible for making lease payments (and that lease payments will be issued before principle/interest payments are due to the bondholder)

- Clear protection against downside risk as a result of the developer posting security.

Though not necessary, a "conduit issuer" - an entity that issues debt on behalf of a state or local government—can be advantageous. A few examples of potential conduit issuers include a county improvement authority (as in New Jersey) or a state-level authority (e.g., a green bank). A conduit issuer typically does not have an independent credit rating (Bailey et al. 2011). The use of a conduit issuer may be advantageous for the following reason: If an administrator issues its own bond via its general obligation taxing authority, the issuance is considered a direct obligation and counts towards the administrator's total debt load. On the other hand, a conduit issuance amounts to a guarantee obligation for the administrator. In contrast with a direct obligation, a guarantee obligation does not count against the total debt the administrator can assume (Pearlman 2011b).

\section{Steps to Hybrid Model Implementation}

In order to set up one or more bond-PPA portfolios or projects, a project team would carry out a number of steps as highlighted in Figure 3, including evaluating the legality and replicability of the model in the state and local context and identifying the public entity that will issue and back the debt. The project team can use a stakeholder process to determine the scope and size of the project. The administrator will need to conduct preliminary engineering analyses to select the sites and elect the project types (roofs, parking structures, building-integrated PV, and/or ground-mount systems).

\section{(1) Evaluate legality in state context}

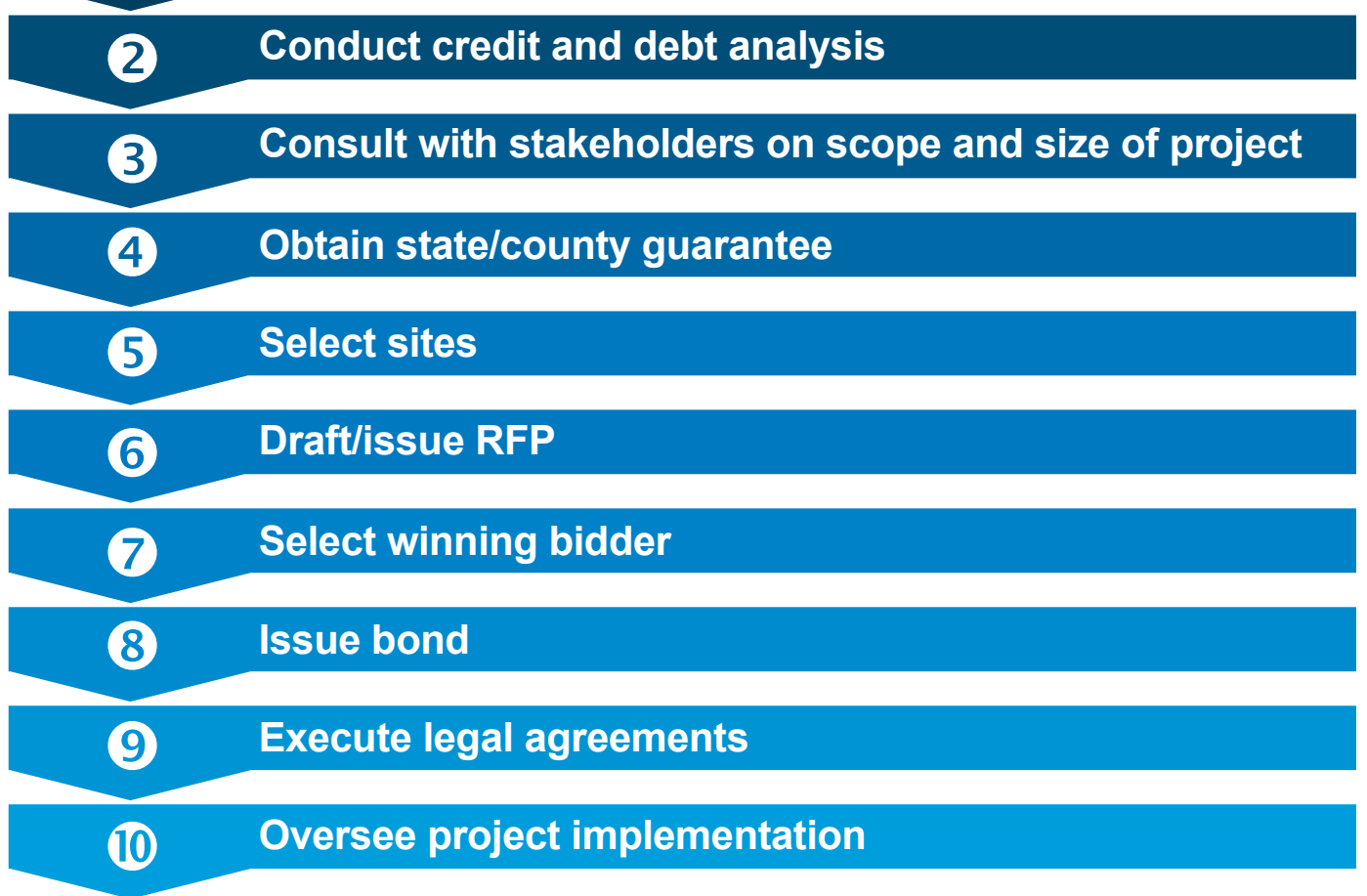

Figure 3. Steps to model implementation 
After selecting the sites, the project team would draft a detailed RFP that lays out the project requirements, timelines, and legal agreements, while leaving room for private sector innovation. The project team can decide whether they will accept alternative proposals from bidders (e.g., proposals that combine public and private funding sources or proposals that accelerate the repayment schedule).

An RFP lays out t he evaluation criteria for selecting the winning bid. These criteria will likely involve financial benefits (PPA price), technical design, project experience, vendor qualifications, and financial strength. An administrator may also include minimum thresholds or bidding requirements; however, it is important not to impose too many restrictions or RFP response may be limited. The project team then evaluates each proposal, selects the winning bidder, and initiates the lease-purchase agreement, security agreement, and PPA.

At this point, the state or local entity issues the bond and executes the legal agreements. This bond can cover $100 \%$ of development costs, development costs minus any equity contribution, or costs as proposed by the winning bidder. At this point, the PPA price may be adjusted upwards or downwards according to the actual bond yield and variations in the administrator's transaction costs (Scerbo 2011). The final step of the process is to oversee project implementation.

\section{Implementation Experience in New Jersey}

As of September 2011, five deals have been finalized using the hybrid model in New Jersey, adding 3.2 MW of solar PV in Morris County, 14.5 MW in Somerset County, 3.4 MW in Union County, and 10 MW in Mercer County. These governments have achieved significant energy cost savings on an NPV basis (see Table 2). Seven other counties in New Jersey are adapting the model. Some are near closing, and some are just starting the process.

Table 2. The Hybrid Model in Action in New Jersey

\begin{tabular}{|c|c|c|c|c|c|}
\hline $\begin{array}{c}\text { County, Tranche, } \\
\text { Year }\end{array}$ & $\begin{array}{c}\text { Local } \\
\text { Hosts }\end{array}$ & $\begin{array}{c}\text { Portfolio } \\
\text { Size }\end{array}$ & $\begin{array}{c}\text { Yr. 1 PPA } \\
\text { Price (\$/kWh) }\end{array}$ & $\begin{array}{c}\text { Annual } \\
\text { Escalator }\end{array}$ & $\begin{array}{c}\text { Energy Cost } \\
\text { Savings (on } \\
\text { an NPV basis) }\end{array}$ \\
\hline $\begin{array}{c}\text { Morris I } \\
(2010)\end{array}$ & 15 & $3.2 \mathrm{MW}$ & $\$ 0.106$ & $3 \%$ & $\$ 3.8 \mathrm{M}$ \\
\hline $\begin{array}{c}\text { Somerset I } \\
(2010)\end{array}$ & 31 & $7.6 \mathrm{MW}$ & $\$ 0.049$ & $2.75 \%$ & $\$ 13.2 \mathrm{M}$ \\
\hline $\begin{array}{c}\text { Union I } \\
(2010)\end{array}$ & 16 & $3.4 \mathrm{MW}$ & $\$ 0.068$ & $2.75 \%$ & $\$ 3.4 \mathrm{M}$ \\
\hline $\begin{array}{c}\text { Somerset II } \\
(2011)\end{array}$ & 33 & $6.9 \mathrm{MW}$ & $\$ 0.041^{2}$ & $3 \%$ & $\$ 11.1 \mathrm{M}$ \\
\hline $\begin{array}{c}\text { Mercer I } \\
(2011)\end{array}$ & 1 & $10.0 \mathrm{MW}$ & $\$ 0.03^{2}$ & $1.5 \%$ & $\$ 14.6 \mathrm{M}$ \\
\hline
\end{tabular}

Source: Morris County 2011; Pearlman 2011b; Somerset County 2011a; Somerset County 2011b; Union County 2010; Santaiti and Price 2011

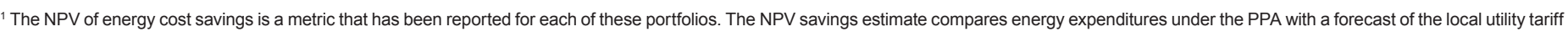

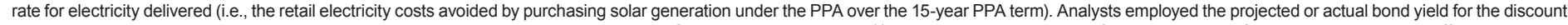

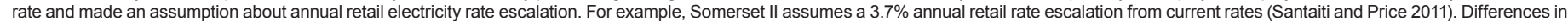

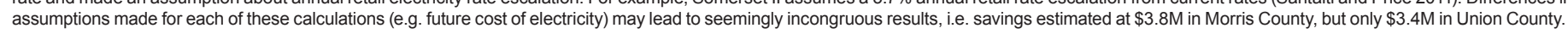

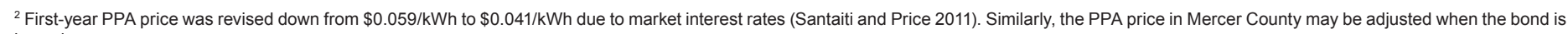
issued. 
A few insights can be gained from studying New Jersey's implementation experience:

- New Jersey implementers have matched the length of the PPA with the length of the lease-purchase agreement and the bond term (15 years in cases to date). Lease and bond repayment schedules have been matched in order to facilitate bond repayment. In Morris and Somerset counties, lease payments are due five months before the amortized bond payments are due to the bondholder.

- New Jersey state law requires that evaluation reports be published regarding the public procurement of solar. These reports examine the solicitation review process, providing insight about how the winning bids were selected. These reports have lead to higher quality proposals in subsequent rounds (Pearlman 2011b). New Jersey administrators have consistently received 4-5 quality proposals in response to an RFP (Scerbo 2011).

- In the first Morris County deal, the original RFP called for a large amount of security; response to the RFP was limited. Consequently, the administrator issued a second RFP to attract more developers. This RFP introduced the "deficiency amount" concept.

- There are tradeoffs to consider when defining the scope of a project. An administrator can increase impact by developing projects on behalf of other local governments. However, working with multiple governments can increase complexities and time requirements. For example, towns that have not implemented solar before may not have solar ordinances and may require more assistance in selecting local hosts. Also, negotiating control of local host sites in multiple local government jurisdictions could be time-intensive. Consequently, the Salem County Improvement Authority has chosen to focus solely on Salem County facilities to expedite the project (Scerbo 2011).

- In the 2010 Somerset County deal, a flexible RFP enabled the winning bidder to repay a full 50\% of project costs within 13 months of entering the contract after receiving a Treasury cash grant (Pearlman 2011b). An additional way that developers have reduced cost has been through the use of in-kind equity [e.g., arranging with the engineering, procurement, and construction (EPC) contractor to postpone payment of labor costs until the Treasury cash grant is received] (Pearlman 2011b).

- In the 2011 Somerset County deal, the administrator actually did not select the lowest PPA price (Somerset County 2011b). The winning bid was selected because it provided stronger financial protection to the county (through offering to self-finance nearly one-third of the capital investment, along with an additional posted security). Furthermore, the proposal also protected the county from the potential risk of reductions in the price of solar renewable energy certificates (SRECs) (Somerset County 2011b).

- It has become common for developer's proposals to include a combination of public- and private-sourced financing (Scerbo 2011). Some developers have determined that reducing the size of the bond can eliminate the need for posted security covering the deficiency amount, as long as the PPA and SREC revenues are enough to cover the debt obligation.

\section{Replicability of the Hybrid Model}

Given these successes, state and local administrators in other states have expressed interest in replicating the hybrid model. Local and state laws and regulations may impact replicability; these laws fall into the following categories:

- Renewable energy law: States must have a sufficient renewable energy standard or similar renewable energy support policy to attract third-party developers. These policies may include renewable portfolio standards, solar set-asides, active renewable energy certificate (REC) markets, tax credits, and other financial incentives.

- Regulations surrounding third-party PPAs: In some states, laws pertaining to the regulation of public utilities limit opportunities for third-party developers to own a host's solar PV system (Kollins et al. 2009; DSIRE 2011). In other states, public utility regulation allows potential project hosts to enter PPAs with third-party developers.

- Laws governing public contracts: Multi-year contracting on the order of 15 or more years is important for enabling a third-party PPA. Statutorily imposed contract length limitations may impede use of the hybrid model by administrators. 
- Laws governing bonding: Requirements and regulations surrounding bond approval and issuance vary by state and locality. The hybrid model is easier to implement if there is a streamlined process for bond approval (e.g., no requirement for voter approval).

- Laws governing public procurement: Administrators may want to select the winning bidder based on criteria beyond price. State and local regulations may vary with respect to how competitive solicitations for goods and services may be structured.

\section{Analysis of Replicability in 10 Key Solar Markets}

The replicability of the hybrid model was evaluated in 10 states: Arizona, California, Colorado, Florida, Hawaii, Massachusetts, North Carolina, Oregon, Pennsylvania, and Texas. These states were selected by blending several criteria: current installed capacity, annual growth rate in recent years, size of the electricity market, and quality of solar resources. In this section, each state is evaluated with respect to its regulations surrounding third-party PPAs, laws governing public contracts, laws governing bonding, and laws governing procurement.

The information provided is intended as a general explanation of laws and regulations relevant to an assessment of the replicability of the hybrid model in municipalities within those 10 states. However, the question of replicability is complex, and a more detailed analysis for each state would be required before implementation could move forward. For example, although the summary and Table 3 on pages 9-10 notes that many of the states allow third-party PPAs, this does not mean that PPA arrangements are permitted statewide in every jurisdiction. In all cases, local counsel should be consulted regarding state and local laws and regulations. In addition, although only minimal information about the relevant tax law in each state has been included, tax credits, exclusions, and other provisions may be important to the feasibility of the hybrid model. Further research in consultation with appropriate tax experts is recommended.

\section{General Conclusions from Replicability Analysis}

\section{Regulations governing third-party PPAs:}

Florida explicitly does not permit third-party PPAs [see Florida PUC Order 17009 (1987)], making Florida an unlikely candidate for the hybrid model. In North Carolina, impediments may exist; entities that wish to enter PPAs with thirdparty developers must submit a petition to the public utility commission [General Statutes§62-3(23)]. The remaining states reviewed have no explicit limitations on the use of PPAs. However, as noted above, there may be restrictions at the local level. Municipal utilities may not allow third-party PPAs in their territories even though PPAs are allowed or are even in use in that particular state's investor-owned utilities' service territories. A review of regulations related to third-party PPAs for all 50 states is available at: http://dsireusa.org/documents/summarymaps/3rd_Party_PPA_map.ppt.

\section{Laws governing public contracts:}

Contract length limitations are not likely to impact the ability of government agencies to enter into PPAs in the majority of the states evaluated; however, in Texas, cities with greater than 5,000 residents are constitutionally restricted from creating debt that exceeds current revenue. Thus, local contracts tend to have "subject to appropriation" clauses. In Colorado and Massachusetts, state law requires governmental agencies to obtain voter approval for public contracts that exceed three years in length. ${ }^{5}$ Obtaining voter approval for a long-term PPA would be time consuming and prohibitive to the hybrid model. However, in practice, government agencies in Colorado have sidestepped the issue by making contracts annually renewable, subject to appropriations (Morrissey 2011). In Massachusetts, municipalities have brought the PPA contract term to vote at a town meeting in order to authorize a longer-term PPA.

\footnotetext{
${ }^{5}$ Colorado's Tax Payer Bill of Rights restricts the use of multi-year financial obligations by government agencies. Massachusetts Gen. Laws Chapter $30 \mathrm{~B}$, Sec. 12 states that unless authorized by majority vote, contracts cannot be awarded for terms exceeding three years.
} 


\section{Laws governing bonding:}

As noted above, bond approval processes affect ease of model implementation. Voter approval requirements prolong the time required to implement the hybrid model and may make it less feasible. Bond approval processes vary significantly between states, municipalities, school districts, and other government agencies. In the jurisdictions reviewed, we found that some forms of bonds require a majority vote from the public, others req uire the vote of a governing body, and others require no approval by vote at all. Revenue bonds are less likely to require voter approval than general obligation bonds because they are paid from revenues generated by the project. Though uncommon, it may be possible to structure the bond used for funding the solar installations with a revenue component. Additionally, approval requirements may vary between different public entities. Potential implementers may factor these distinctions into whether the model is best implemented at the state level, at the local level, within school districts, or through the creation of a special district.

\section{Laws governing procurement:}

Our review found that competitive sealed bidding and competitive sealed proposals are the most common procurement approaches used by states and local governments. In certain cases, municipalities may be able to enter into direct contracts (e.g., for professional services, where a contractor's license would be pulled in the case of non-performance). Selection criteria for competitive solicitations may be narrowly defined as price or may include ancillary characteristics like developer experience and qualifications, quality, workmanship, and suitability for a particular purpose. In some states, these evaluation criteria must be established in advance, while other states may not make this an explicit requirement. Finally, states may or may not permit procurement of multiple projects under one contract. Table 3 summarizes state and local rules and regulations that impact replicability of the hybrid model in the 10 states evaluated. Following the table, relevant statute numbers are listed in a text box.

Table 3. Summary of State and Local Laws Related to Bond-PPA Financing in 10 Key Solar Markets

\begin{tabular}{|c|c|c|c|}
\hline State & $\begin{array}{l}\text { PPA Legality and Public } \\
\text { Contracting for Long-Term } \\
\text { Power Purchase }\end{array}$ & $\begin{array}{l}\text { Laws Governing Bond Issuance } \\
\text { and Approval }\end{array}$ & $\begin{array}{l}\text { Laws Governing } \\
\text { Procurement }\end{array}$ \\
\hline$A Z$ & $\begin{array}{l}\text { - PPAs are allowed. } \\
\text { - No specific restrictions on } \\
\text { long-term power contracts } \\
\text { found. }\end{array}$ & $\begin{array}{l}\text { Voter approval is required for } \\
\text { general obligation (GO) bonds } \\
\text { but not for revenue bonds. }\end{array}$ & $\begin{array}{l}\text { - Government agencies may award multiple } \\
\text { projects under a single procurement. } \\
\text { - Counties and cities may have different pro- } \\
\text { curement standards. } \\
\text { - Selection criteria may include demonstration } \\
\text { of competence and other qualifications. }\end{array}$ \\
\hline CA & $\begin{array}{l}\text { - PPAs are allowed. } \\
\text { - No specific restrictions on } \\
\text { long-term power contracts } \\
\text { found. }\end{array}$ & $\begin{array}{l}\text { Voter approval is not required } \\
\text { for issuance of conduit or Mark } \\
\text { Roos* revenue bonds. }\end{array}$ & $\begin{array}{l}\text { - General rule that competitive sealed bidding for } \\
\text { state and local contracts greater than } \$ 75,000 \text {. } \\
\text { - Exceptions exist (e.g., higher education entities). }\end{array}$ \\
\hline $\mathrm{CO}$ & $\begin{array}{l}\text { - PPAs are allowed. } \\
\text { - Voter approval required for } \\
\text { multi-year contracts. } \\
\text { - PPAs in CO have been } \\
\text { structured as annually } \\
\text { renewable contracts subject } \\
\text { to appropriation. }\end{array}$ & $\begin{array}{l}\text { State: no general state authority } \\
\text { to issue GO or revenue bonds, } \\
\text { but the state government can } \\
\text { create special entities to issue } \\
\text { bonds. } \\
\text { Local: voter approval is required } \\
\text { for GO bonds but not for revenue } \\
\text { bonds. }\end{array}$ & $\begin{array}{l}\text { - Contracts are awarded through competitive } \\
\text { sealed bidding (unless otherwise authorized by } \\
\text { law). } \\
\text { - A total value proposition (not just lowest cost) is } \\
\text { used to evaluate an RFP. } \\
\text { - A single RFP can be used for multiple projects. }\end{array}$ \\
\hline FL & - PPAs are not permissible. & - N/A & - N/A \\
\hline $\mathrm{HI}$ & $\begin{array}{l}\text { - PPAs are allowed } \\
\text { - Long-term power contracts } \\
\text { explicitly allowed. }\end{array}$ & $\begin{array}{l}\text { Voter approval is not required for } \\
\text { revenue bonds but issuance may } \\
\text { be put to vote of governing body. }\end{array}$ & $\begin{array}{l}\text { - Generally, competitive sealed bid or competitive } \\
\text { sealed proposal. }\end{array}$ \\
\hline
\end{tabular}




\begin{tabular}{|c|c|c|c|}
\hline State & $\begin{array}{l}\text { PPA Legality and Public } \\
\text { Contracting for Long-Term } \\
\text { Power Purchase }\end{array}$ & $\begin{array}{c}\text { Laws Governing Bond Issuance } \\
\text { and Approval }\end{array}$ & $\begin{array}{l}\text { Laws Governing } \\
\text { Procurement }\end{array}$ \\
\hline MA & $\begin{array}{l}\text { - PPAs are allowed. } \\
\text { - Contract length limited to } 3 \\
\text { years unless authorized by } \\
\text { majority vote. }\end{array}$ & $\begin{array}{l}\text { - Majority vote by public or govern- } \\
\text { ing body may be required for } \\
\text { revenue bonds, depending on } \\
\text { local jurisdiction. } \\
\text { - Public meeting may also be } \\
\text { required. }\end{array}$ & $\begin{array}{l}\text { - Competitive sealed bidding, required for con- } \\
\text { tracts }>\$ 25,000 \text {. } \\
\text { - Other selection criteria are allowed: quality, } \\
\text { workmanship, and suitability for a particular } \\
\text { purpose. }\end{array}$ \\
\hline NC & $\begin{array}{l}\text { - PPA: Impediments may } \\
\text { exist, possible with gov't } \\
\text { commission petition. } \\
\text { - Long-term power contracts } \\
\text { explicitly allowed for cities, } \\
\text { counties, or joint municipal } \\
\text { power agencies, so long as } \\
\text { entity has sufficient funds for } \\
\text { the upcoming year. }\end{array}$ & $\begin{array}{l}\text { Voter approval is not required for } \\
\text { revenue bonds. } \\
\text { - PUC must approve all revenue } \\
\text { bonds for energy-related projects. } \\
\text { - Local Gov't Commission must } \\
\text { approve all local entity projects. }\end{array}$ & $\begin{array}{l}\text { - Competitive bids or RFPs. } \\
\text { - If a project qualifies as a Guaranteed Energy } \\
\text { Savings Contract, it may be exempt from the } \\
\text { competitive bid requirements. }\end{array}$ \\
\hline OR & $\begin{array}{l}\text { - PPAs are allowed. } \\
\text { - No specific restrictions on } \\
\text { long-term power contracts } \\
\text { found. }\end{array}$ & $\begin{array}{l}\text { - Local revenue bonds require } \\
\text { voter approval, while state } \\
\text { revenue bonds (including energy } \\
\text { project bonds) do not. } \\
\text { - May vary by entity (i.e., special } \\
\text { districts, ports, and colleges may } \\
\text { not require voter approval). }\end{array}$ & $\begin{array}{l}\text { - Competitive bid or RFP process used for most } \\
\text { state procurements. } \\
\text { - City rules may vary and may include competitive } \\
\text { negotiations, competitive sealed bidding, or } \\
\text { other procurement methods. }\end{array}$ \\
\hline PA & $\begin{array}{l}\text { - PPAs are allowed } \\
\text { - No specific restrictions on } \\
\text { long-term power contracts } \\
\text { found. }\end{array}$ & $\begin{array}{l}\text { State: revenue bonds may be } \\
\text { issued by the Commonwealth } \\
\text { Financing Authority; these bonds } \\
\text { may not be debtliability of the } \\
\text { Commonwealth and must be } \\
\text { paid from accounts authorized for } \\
\text { repayment. } \\
\text { - Local: governments may issue } \\
\text { bonds by ordinance; Reports } \\
\text { from city chief financial officer \& } \\
\text { solicitor are required for revenue } \\
\text { bonds. }\end{array}$ & $\begin{array}{l}\text { - Competitive sealed bidding, unless otherwise } \\
\text { authorized by law. } \\
\text { - Criteria such as inspection, testing, quality, work- } \\
\text { manship, delivery, and suitability for a particular } \\
\text { purpose. } \\
\text { - The invitation for bids must set forth all } \\
\text { evaluation criteria and relative importance of } \\
\text { the criteria must be established prior to the } \\
\text { invitation. }\end{array}$ \\
\hline TX & $\begin{array}{l}\text { - PPAs are allowed, effective } \\
\text { September } 2011 . \\
\text { - Cities are constitutionally } \\
\text { restricted from creating } \\
\text { debt that exceeds current } \\
\text { revenue, thus local contracts } \\
\text { tend to have "subject to } \\
\text { appropriation" clauses. }\end{array}$ & $\begin{array}{l}\text { - Governing body (state or local) } \\
\text { can issue bonds to finance public } \\
\text { improvements, including energy } \\
\text { projects. } \\
\text { - State: bonds subject to review of } \\
\text { Bond Review Board. } \\
\text { - Local: bonds may be subject to } \\
\text { other certain restrictions. }\end{array}$ & $\begin{array}{l}\text { - Competitive bidding or competitive sealed } \\
\text { proposals. } \\
\text { - Government entity may consider: quality, } \\
\text { vendor's reputation, vendor's past relationship } \\
\text { with government, PPA price, total long-term cost } \\
\text { to government, and other relevant factors. }\end{array}$ \\
\hline
\end{tabular}

* In California, multiple agencies can join together to issue what is called a Marks-Roos revenue bond, named after the 1985 Marks-Roos Bond Pooling Act.

Sources: DSIRE 2011, Keyes \& Fox LLP 2011.

\section{Notes on Relevant Statutes:}

1. Arizona - PPA: ACC Decision 71795; Procurement: ARS Title 41, Ch. 23, Art. 5.

2. California - PPA: Public Utility Code $\S 218, \S 2868$

3. Colorado - PPA: S.B. 09-051; PUC Decision C09-0990; Local bonds: CRS 29-3-101 et seq.; Procurement: CRS 24-103-201, CRS 24-103-202; Public contracting: Tax Payers' Bill of Rights (“TABOR amendment”)

4. Florida - PPA: PUC Decision: Docket 860725-EU; Order 17009 (1987).

5. Hawaii - PPA: H.B. 704 (2011); Public contracting: Hawaii Statute $\S 103 D-315$ 
6. Massachusetts - PPA: 220 CMR 18.00; Public contracting: Mass. Gen. Laws Ch. 30B Sec. 12; Procurement: Mass. Gen Laws Ch. 30B Sec. 5.

7. North Carolina - PPA: General Statutes § 62-3(23); Bonds: NC Stat. Art. 5, §159-80 et seq.; Procurement: NC Stat. § 143-64.17A (energy performance contracts); Public contracting: §160A-17, §153A-13, §159-41

8. Oregon - PPA: PUC Order, Docket 08-388; Bonds: ORS 287A.150; Procurement: ORS 279B

9. Pennsylvania - PPA: PUC Order, Docket M-00051865; Bonds: 64 Pa.Cons. Stat. § 1521, 53 Pa.C.S. §15893 et seq.; Procurement: 62 Pa.C.S. $\S 511-513$

10. Texas - PPA: SB 981, 2011, § 39.916; Bonds: Government Code 1371, 1231, 1301-1333; Procurement: Local Gov’t Code $\S 271.113$ Public contracting: TX Constitutional Art. XI § 5; Local Gov’t Code $§ 271.903$.

Apart from Florida, where PPAs are not allowed, significant legal barriers to the hybrid model do not appear in the states evaluated. The factors considered for these 10 states could be applied to any state to determine if the threshold conditions for implementation exist. The most significant barriers may prove to be the strong credit rating needed to enable the model and the time, money, and expertise needed to implement it.

\section{Conclusion}

Interest in the hybrid model is increasing nationwide due to its promise of reducing the cost of purchasing solar power. The model is likely to remain attractive to public entities as long as publically sourced capital is cheaper than what can be obtained in the private market. Public funding may reduce the cost of debt by reducing the interest rate and associated lender or investor fees. Finally, completing large public projects may help increase awareness of solar technology, jumpstart the use of the technology in a particular jurisdiction, and attract solar businesses. To determine if the hybrid model may be implemented in a specific jurisdiction, consideration of the factors set out above and consultation with tax and legal advisors is recommended.

\section{Contact Information}

For additional information, please contact:

General inquiries: Karlynn Cory, Senior Energy Analyst, National Renewable Energy Laboratory, Tel. (303) 384-7464, email: karlynn.cory@nrel.gov

Implementation experience: Stephen B. Pearlman, Partner, Inglesino, Pearlman, Wyciskala \& Taylor, LLC, Tel. (973) 947-7133, email: spearlman@iandplaw.com

Replicability: Kathleen D. Kapla, Of Counsel, Keyes \& Fox LLP, Tel. (510) 314-8220, email: kkapla@keyesandfox.com

Replicability: Kevin T. Fox, Partner, Keyes \& Fox LLP, Tel. (510) 314-8201, email: kfox@,keyesandfox.com

\section{Acknowledgments}

This Fact Sheet was produced, researched and written by Claire Kreycik, who recently left NREL. The Finance Analysis Team owes her a debt of gratitude for all of her contributions during her tenure. Thanks also to the legal team of Keyes \& Fox LLP for their research and analyses of the replicability of the hybrid model in 10 key states. 


\section{References}

Bailey, M.; Cholst, D.; Magnatta, G.T. (June 2011). "Tax Exempt Bonds: The Role of Conduit Issuers in Tax Compliance." The Advisory Committee on Tax Exempt and Government Entities (ACT) White Paper.

Cory, K.; Canavan, B.; Koenig, R. (October 2009). Power Purchase Agreement Checklist for State and Local Governments. NREL/FS-6A2-46668. Golden, CO:

National Renewable Energy Laboratory. http://www.nrel.gov/docs/fy10osti/46668.pdf. Accessed August 18, 2011.

Cory, K.; Coggeshall, C.; Coughlin, J. (May 2008). Solar Photovoltaic Financing: Deployment on Public Property by State and Local Governments. TP-670-43115. Golden, CO: National Renewable Energy Laboratory. http://www.nrel.gov/docs/ fy08osti/43115.pdf. Accessed August 18, 2011.

Database of State Incentives for Renewables and Efficiency (DSIRE). (2011). "3rd-Party Solar PV Power Purchase Agreements (PPAs)." http://dsireusa.org/ documents/summarymaps/3rd_Party_PPA_map.ppt. Accessed August 18, 2011.

Keyes and Fox, LLP. (28 June 2011). Memorandum, Morris County, NJ, Bond/PPA Model: Replicability for Other States.

Kollins, K.; Speer, B.; Cory, K. (November 2009). Solar PV Project Financing: Regulatory and Legislative Challenges for Third-Party PPA System Owners. TP-6A246723. Golden, CO: National Renewable Energy Laboratory, 55pp. http://www.nrel. gov/docs/fy10osti/46723.pdf. Accessed August 18, 2011.

Mercer County (2011). “30. Renewable Energy Program Evaluation Report.” http:// www.mcia-nj.com/rfp_q.aspx Accessed September 14, 2011.

Morris County. (2011). “The Morris Model: Our Renewable Energy Program.” http:// www.co.morris.nj.us/improvement/renewable.asp. Accessed August 18, 2011.

Morrissey, S. (14 July 2011). Email. Greenprint Denver, Denver, CO.

Pearlman, S. (24 February 2011a). "Solar Power Purchase Agreements (PPA):

Financing Options for Local Governments - Hybrid Option (Morris Model).” Webinar presented at the Council of State Governments, Eastern Regional Conference.

Pearlman, S. (28 March 2011b). Phone interview. Inglesino, Pearlman, Wyciskala \& Taylor, LLC, Morristown, NJ.

Santaiti, J.; Price, J. (26 August 2011). Memorandum, SCIA Solar Tranche II - Savings Update. Gabel Associates.

Scerbo, R. (12 September 2011). Phone interview. DeCotiis, FitzPatrick \& Cole, LLP, Teaneck, NJ.

Somerset County. (2011a). "Solar Proposal Tranche I Evaluation Report.” http://www. scia.co.somerset.nj.us/newprojects.htm. Accessed August 18, 2011.

Somerset County. (2011b). "Solar Proposal Tranche II Evaluation Report." http://www. scia.co.somerset.nj.us/newprojects.htm. Accessed August 18, 2011.

Union County. (2010). “Solar Proposal Evaluation Report.” http://www.ucianj.org/ RFPsolar2010.asp. Accessed August 18, 2011.

\section{WNREL}

Photovoltaic (PV) research at

the National Renewable Energy

Laboratory (NREL) focuses on

boosting solar cell conversion

efficiencies, lowering the cost of

solar cells, modules, and systems,

and improving the reliability of

PV components and systems.

NREL's PV effort contributes to

these goals through fundamental

research, advanced materials

and devices, and technology

development.

National Renewable

Energy Laboratory

1617 Cole Boulevard

Golden, Colorado 80401

303-275-3000 • www.nrel.gov

NREL is a national laboratory of the U.S. Department of Energy, Office of Energy Efficiency and Renewable Energy, operated by the Alliance for Sustainable Energy, LLC.

NREL/BR-6A20-53622 • December 2011 